\title{
Industrial Wastewater Treatment: A Challenging Task in the Industrial Waste Management \\ Shah MP*
}

Industrial Waste Water Research Laboratory, Division of Applied and Environmental Microbiology, Enviro Technology Limited, Gujarat, India

\begin{abstract}
This review shows the pros and cons of using the combination of various technologies for industrial waste water treatment plant. Rapid industrialization, intensive agriculture and other human activities cause soil degradation, pollution and lowers the productivity and sustainability of the crops that further increase the pressure on natural resources and contribute to their degradation. Environmental bio remediation is an effective management tool for managing the polluted environment and in restoring the contaminated soil. The use of microbial sources, coupled with advanced technology is one of the most promising and economic strategies for the removal of environmental pollutants. There is a strong scientific growth with both the in situ and ex situ ways of bio remediation, in part due increased use of natural damping as most of the natural attenuation is due to bio degradation. The degradation of pollutants by environmental bio remediation technology, can be a lucrative and environmentally friendly alternative. This article provides an overview of the important environmental bioremediation technologies and their application in treating the industrial waste water.
\end{abstract}

Keywords: Bio-remediation; Bio-degradation; Bacteria; Environment; Waste water

\section{Introduction}

To deal with effluents, the traditional end-of-pipe solutions coming out of the production plant have gradually been substituted for an increased decentralized approach to treat the selected wastewater streams in the most effective and economical way [1]. Further, additional goals like reducing the overall effluent emissions by recycling the treated wastewater towards zero-discharge strategies or minimizing waste generation and disposal costs have gradually been incorporated to both water and wastewater management approach. The future of industrial wastewater treatment has two main targets:

\section{$\alpha$. Monitoring and abatement of trace pollutants;}

$\beta$. Further development of the existing and new wastewater treatment technologies in order to minimize the costs and optimize resource consumption.

Environmental pollution is the most atrocious ecological crisis that man is facing today. Pollution is a global intimidation to the environment and it becomes an alarm word of today's world. The swift growth of human populations fulled by scientific developments in health and agriculture has led to a speedy increase in the environmental pollution. Water has a major impact on all aspects of human life, including but not limited to health, food, energy and the economy. The unprecedented inhabitants' multiplies and the industrial development during the $20^{\text {th }}$ century has not only increased the conventional solid and liquid waste pollutants to critical levels but also produced a range of previously unknown pollution problems for which the society was unprepared. Of the total 220 million deaths per year it was estimated that the causes of death in 12-20 million are due to water and nonfatal infections which is very high [2]. The run- off flow is considered to be the freshwater source on which the people depend. The steady flow of fresh water was estimated at 12.700 to $16.000 \mathrm{~km}^{3}$ year which is $4200 \mathrm{~km}^{3}$ per year. It is used for freshwater irrigation, industrial and domestic purposes, and that is estimated to increase by a number of $4350-5200 \mathrm{~km}^{3}$ per year. Alternatively, the available fresh water is only $0.5 \%$ of the worlds 1.4 billion $\mathrm{km}^{3}$ water, which is also poorly distributed throughout the world [3]. There is a limited ability to increase the supply of drinking water due to the competing demands of the growing populations worldwide and, the problems related to water. It is expected to further increase due to climatic changes and population growth over the next two decades. The most common method of wastewater treatment in the developed countries is centralized aerobic wastewater treatment plants and lagoons for both domestic and industrial waste water. It is estimated that the world's population increases roughly by 2.9 billion people between now and 2050 . The lack of delivery of drinking water is the result of the use of water resources for domestic, industrial and irrigation purposes by many due to growing global demand for food, energy, etc. and will be much more increased as a result population growth and the further threat of climate changes [4]. The polluted surface/ground water resources, is another cause of reduced fresh water supplies. The aquifers worldwide are thinner and are contaminated as a result of many problems of intrusion of salt water, soil erosion, lack of hygiene, contamination of soil/surface water algae growth, detergents, fertilizers, pesticides, chemicals, heavy metals, and so on. The domestic wastewater can also be treated on site using septic systems. It is an advanced system which can treat wastewater from one or more households. It consists of an anaerobic underground tank and the drainage field for the treatment of effluent from the tank. The quantity of wastewater treatment varies in many developing countries [5]. In some instances, the industrial waste water is discharged directly into water bodies, while large industrial facilities can have a full race treatment. In some coastal cities, the domestic wastewater is discharged directly into the ocean. Waste pits are lined or unlined holes to a depth of several meters, which can be equipped for comfort. Figure 1 shows the different ways for wastewater treatment and discharge.

*Corresponding author: Mr. Maulin Shah P, Industrial Waste Water Research Laboratory, Division of Applied and Environmental Microbiology, Enviro Technology Limited, Gujarat, India, Tel: 9989365485; E-mail: shahmp@beil.co.in

Received October 15, 2016; Accepted November 14, 2016; Published November 21, 2016

Citation: Shah MP (2016) Industrial Wastewater Treatment: A Challenging Task in the Industrial Waste Management. Adv Recycling Waste Manag 2: 115. DOI: 10.4172/2475-7675.1000115

Copyright: () 2016 Shah MP. This is an open-access article distributed under the terms of the Creative Commons Attribution License, which permits unrestricted use, distribution, and reproduction in any medium, provided the original author and source are credited. 


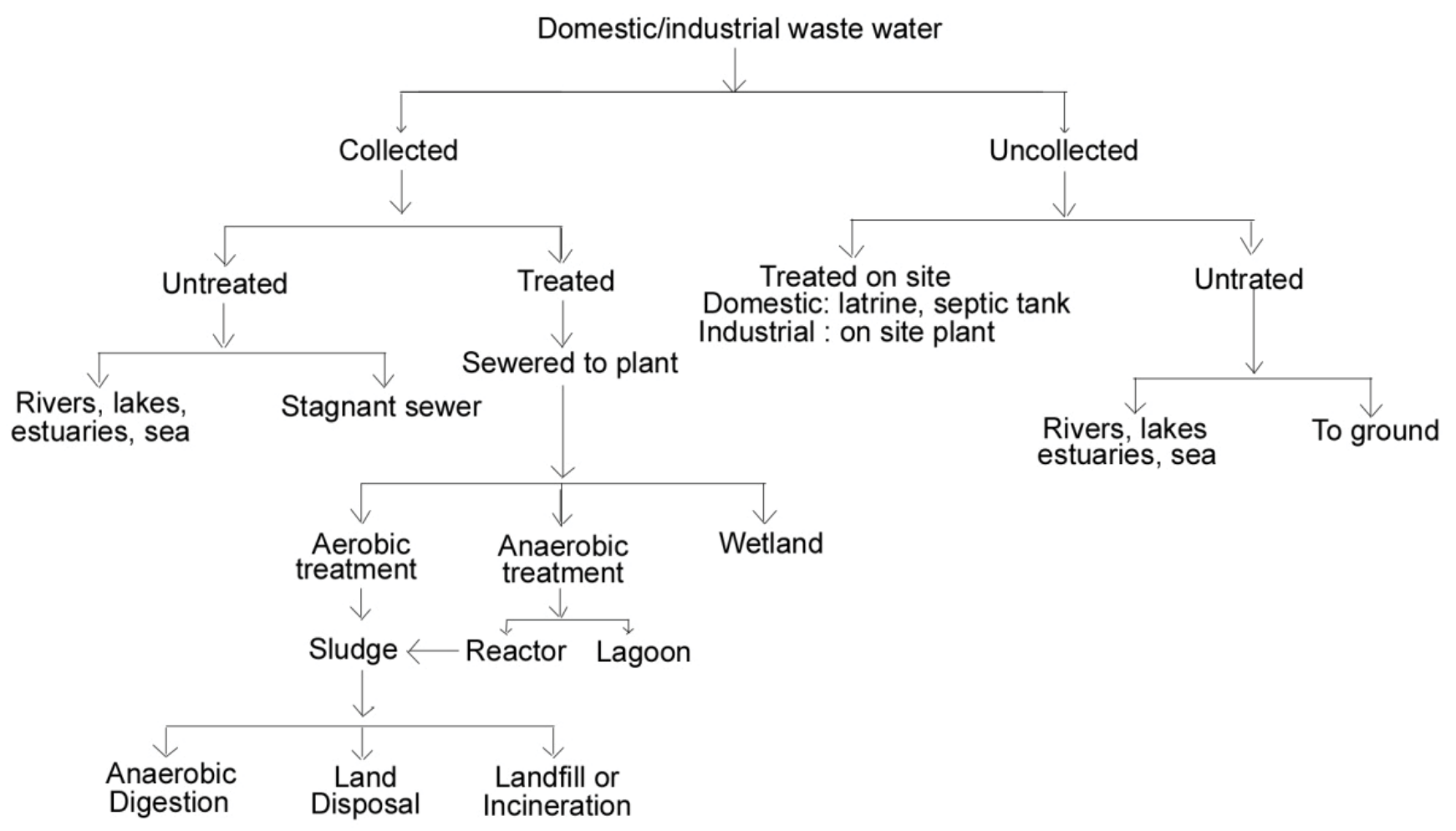

Figure 1: Domestic/industrial wastewater treatment system and discharge scheme.

\section{Wastewater treatment technologies}

In waste water treatment technology, various physical, chemical and biological pre-treatment and after treatment can be used to treat raw wastewater. Physico-chemical techniques include membrane filtration, coagulation, flocculation, precipitation, flotation, adsorption, ion exchange, mineralization, advanced oxidation, electrolysis and chemical reduction. Biological treatment systems effectively remove toxic pollutants of large volumes of wastewater at low costs and are preferred alternatives [6]. Biological techniques, including biosorption and bio degradation in aerobic, anaerobic or combined aerobic/ anaerobic treatment processes of bacteria, fungi, plants, yeasts, algae and enzymes are known. Generally, the wastewater is highly colored with high biological oxygen demand and chemical oxygen demand and has high conductivity and is alkaline in nature [7]. For this reason, several factors determine the technical and economic feasibility of each removal techniques such as pigment type dyes, wastewater composition, dose and cost of the necessary chemicals, operating costs (energy and materials), environmental fate, and handling costs of generated waste products. Usually, it may not be sufficient to obtain full use of one of the individual processes, because each method has its limitations. The type treatment is choosed based on several factors such as the type of pollutants that should be treated, composition of the wastewater, the cost of the necessary chemicals and operation costs, handling and costs of the waste product generated [8]. Contemporaneous with the in-house multi-dimensional pollution minimization efforts, a number of emerging material recovery/reuse and end-of-pipe wastewater treatment technologies are being projected and explored at different stages of commercialization. Accordingly, despite the fact that virtually all the known physico-chemical and biological techniques have been explored for wastewater treatment, none has emerged as a panacea. Cost-competitive biological options are rather ineffective while physico-chemical processes are restricted in scale of operation and pollution profile of the effluent [9]. Figure 2 depicts a simplified representation of the proposed combinations.

This article gives an inclusive overview of the impending of hybrid technology for treating wastewater. Analogously to the above trends, the combinations were placed in the three broad categories, i.e., a combination of the advanced oxidation process, a combination of physico-chemical treatments between themselves and those with advanced oxidation process, and the one of primary importance, is the combination of biological systems with conventional physico- chemical processes and advanced oxidation process (Figure 3 ).

The hazardous organic waste that is widely spread in water by industrial and domestic sources is an emerging issue [10]. Advanced Oxidation Processes (AOP) are efficient methods that remove the non degradable organic pollutants by means of biological processes. They involve the production of extremely reactive oxygen species that are able to obliterate a broad choice of organic compounds [11]. AOP are driven by an external energy sources such as electric power, ultraviolet radiation or solar light, so these processes are often more costly than traditional biological wastewater treatment. Furthermore, the AOP can be applied for the disinfection of water, air and for remediation of contaminated soils [12-15]. Table 1 lists the advantages and disadvantages of different individual techniques. It appears that a single, universally applicable end-of-pipe solution is unrealistic, and combination of different techniques is required to devise a technically and economically viable choice. In light of this, the researchers have put forward a wide range of hybrid decolorization techniques. 
Citation: Shah MP (2016) Industrial Wastewater Treatment: A Challenging Task in the Industrial Waste Management. Adv Recycling Waste Manag 2: 115 . DOI: $10.4172 / 2475-7675.1000115$

Page 3 of 11

\begin{tabular}{|c|c|c|c|}
\hline Process & Advantages & Disadvantages & References \\
\hline (A) Biological & $\begin{array}{l}\text { Cost-competitive option. Direct, disperse and basic dyes } \\
\text { have high level of adsorption on to activated sludge }\end{array}$ & $\begin{array}{l}\text { Dyes are generally toxic and very resistant to bio } \\
\text { degradation. Acid and reactive dyes are highly water- } \\
\text { soluble and have poor adsorption on to sludge. }\end{array}$ & {$[16]$} \\
\hline (B) Coagulation & $\begin{array}{l}\text { Economically feasible; satisfactory removal of disperse, } \\
\text { sulphur and vat dyes. }\end{array}$ & $\begin{array}{l}\text { Removal is } \mathrm{pH} \text { dependent; produces large } \\
\text { quantity of sludge. May not remove highly soluble } \\
\text { dyes; unsatisfactory result with azo, reactive, acid } \\
\text { and basic dyes. }\end{array}$ & {$[17-19]$} \\
\hline (C) Activated C adsorption & $\begin{array}{l}\text { Good removal of wide variety of dyes, namely, azo, } \\
\text { reactive and acid dyes; especially suitable for basic dye. }\end{array}$ & $\begin{array}{l}\text { Removal is } \mathrm{pH} \text { dependent; unsatisfactory result } \\
\text { for disperse, sulfur and vat dyes. } \\
\text { Regeneration is expensive and involves } \\
\text { adsorbent loss; necessitates costly disposal. }\end{array}$ & [20] \\
\hline (D) lon exchange & $\begin{array}{l}\text { Adsorbent can be regenerated without loss, dye } \\
\text { recovery conceptually possible. }\end{array}$ & $\begin{array}{l}\text { lon exchange resins are dye-specific; } \\
\text { regeneration is expensive; large-scale dye } \\
\text { recovery cost-prohibitive. }\end{array}$ & {$[21,22]$} \\
\hline (E) Chemical oxidation & Initiates and accelerates azo-bond cleavage. & $\begin{array}{l}\text { Thermodynamic and kinetic limitations along } \\
\text { with secondary pollution are associated with } \\
\text { different oxidants. Not applicable for disperse } \\
\text { dyes. Negligible mineralization possible, release } \\
\text { of aromatic amines and additional contamination } \\
\text { with chlorine (in case of } \mathrm{NaOCl} \text { ) is suspected. }\end{array}$ & [23] \\
\hline (F) Advanced oxidation processes (AOP) & $\begin{array}{l}\text { Generate a large number of highly reactive free } \\
\text { radicals and by far surpass the conventional oxidants } \\
\text { in decolorization }\end{array}$ & $\begin{array}{l}\text { AOPs in general may produce further undesirable } \\
\text { toxic byproducts and complete mineralization may } \\
\text { not be possible. Presences of radical scavengers } \\
\text { reduce efficiency of the processes some of } \\
\text { which are pH dependent. Cost-prohibitive at their } \\
\text { present stage of development. }\end{array}$ & {$[23,24]$} \\
\hline (1) UV/O3 & $\begin{array}{l}\text { Applied in gaseous state, no alteration of volume. } \\
\text { Good removal of almost all types of dyes; especially } \\
\text { suitable for reactive dyes. Involves no sludge formation, } \\
\text { necessitates short reaction times. }\end{array}$ & $\begin{array}{l}\text { Removal is } \mathrm{pH} \text { dependent (neutral to slightly } \\
\text { alkaline); poor removal of disperse dyes. } \\
\text { Problematic handling, impose additional loading } \\
\text { of water with ozone. } \\
\text { Negligible or no COD removal. High cost of } \\
\text { generation coupled with very short half-life and } \\
\text { gas-liquid mass transfer limitation }\end{array}$ & {$[25-30]$} \\
\hline (2) UV/H2O2 & $\begin{array}{l}\text { Involves no sludge formation, necessitates short } \\
\text { reaction times and COD reductionmay be possible to } \\
\text { some extent. }\end{array}$ & $\begin{array}{l}\text { Not applicable for all dye types, requires } \\
\text { separation of suspended solid and suffers from } \\
\text { UV light penetration limitation. Lower pH required } \\
\text { to nullify effect of radical scavengers. }\end{array}$ & [31] \\
\hline (3) Fenton's reagent & $\begin{array}{l}\text { Effective decolorization of both soluble and insoluble } \\
\text { dyes; applicable even with high suspended solid } \\
\text { concentration. Simple equipment and } \\
\text { easy implementation. Reduction of COD (except with } \\
\text { reactive dyes) possible. }\end{array}$ & $\begin{array}{l}\text { Effective within narrow } \mathrm{pH} \text { range of }<3.5 \text {; and } \\
\text { involves sludge generation. } \\
\text { Comparatively longer reaction time required }\end{array}$ & [32] \\
\hline (4) Photocatalysis & $\begin{array}{l}\text { No sludge production, considerable reduction of COD, } \\
\text { potential of solar light utilization. }\end{array}$ & $\begin{array}{l}\text { Light penetration limitation, fouling of catalysts, } \\
\text { and problem of fine catalyst separation from the } \\
\text { treated liquid (slurry reactors) }\end{array}$ & [33] \\
\hline (5) Electrochemical & $\begin{array}{l}\text { Effective decolorization of soluble/insoluble dyes; } \\
\text { reduction of COD possible. Not affected by presence of } \\
\text { salt in wastewater. }\end{array}$ & $\begin{array}{l}\text { Sludge production and secondary pollution } \\
\text { (from chlorinated organics, heavy metals) are } \\
\text { associated with electrocoagulation and indirect } \\
\text { oxidation, respectively. } \\
\text { Direct anodic oxidation requires further } \\
\text { development for industrial acceptance. } \\
\text { High cost of electricity is an impediment. } \\
\text { Efficiency depends on dye nature. }\end{array}$ & [34] \\
\hline
\end{tabular}

Table 1: Advantages and shortcomings of individual dye wastewater treatment techniques.

AOP refer to a set of oxidative water treatments that can be used to treat toxic effluents at industrial level and wastewater treatment plants. AOP are flourishing to transform toxic organic compounds into biodegradable substances. In general AOP are economical to set up but comprise high operating fixed cost due to the input of chemicals and requirement of the power required [35-40]. To limit the costs, AOP are often used as pre-treatment mixed with biologic treatment. Advanced oxidation was recently used as quaternary action or a shining step to remove micro-pollutants from the effluents of municipal wastewater treatment plants and for the disinfection of water. The combination of several AOP is an efficient way to increase the removal of pollutants and in reducing the costs [41-43].

\section{Advanced oxidation process system}

Advanced oxidation involves several steps represented schematically in the figure below and explained as follows:

1. Formation of strong oxidants.

2. The reaction of these oxidants with organic substances in water to produce biodegradable intermediates.

3. Further reaction of biodegradable intermediates with oxidants leading to mineralization. 


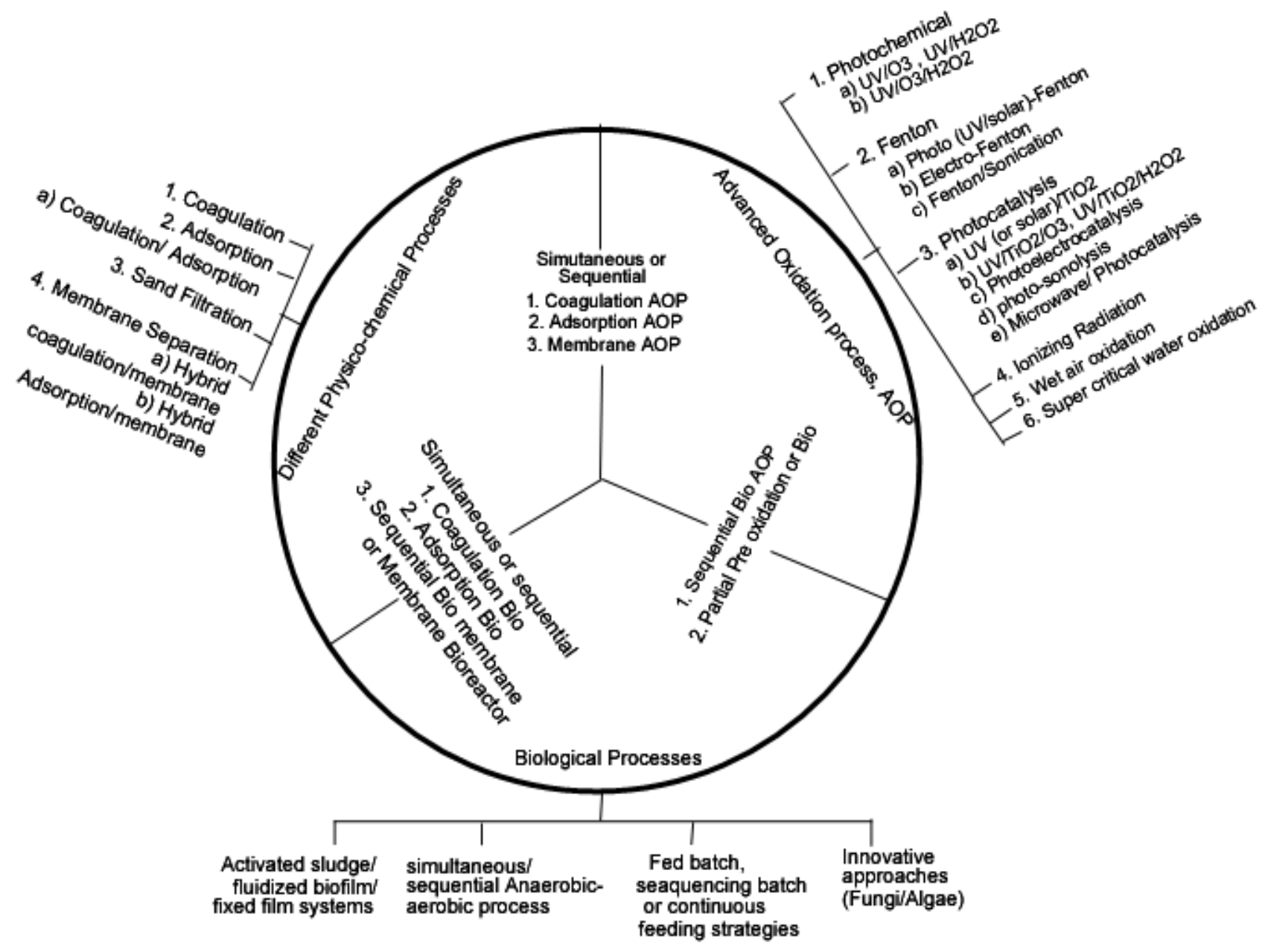

Figure 2: Simplified representation of broad spectrum of combinations proposed in the literature.

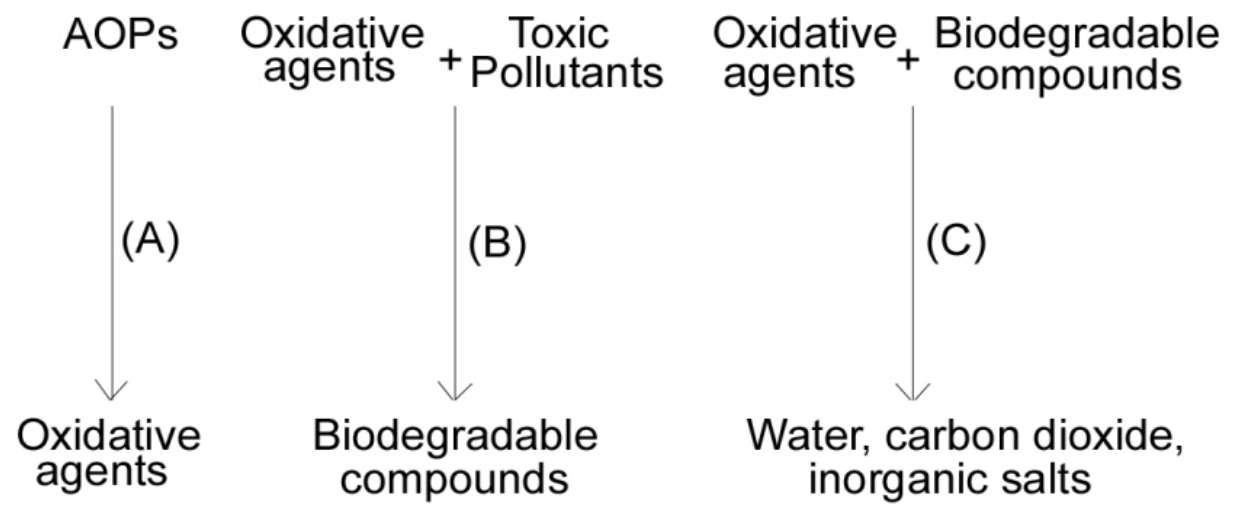

Figure 3: Advanced Oxidation Process Scheme.

\section{Advanced oxidation process combination}

AOS have been calculated extensively for wastewater treatment but their commercialization has not yet been realized because of prevailing barriers. These processes are prohibitively expensive and complex at the current level of development. Additional obstacle in the waste water treatment is the existence of relatively high concentration of colorants, and AOS are the only effective ways for wastewater treatment [44-50]. 
Thus, significant dilution is necessary, as a requirement of the device. The presence of dye additives/impurities such as synthetic precursors, by-products, salts and dispersing agents in a commercial dye bath formulation, cause further reduction in the process efficiency. Although small laboratory investigations reveal encouraging results, such studies are not sufficient to explain the practical feasibility of AOP [51,52].

\section{Photochemical process}

The photo-activated chemical reactions are characterized by a free radical mechanism initiated by the interaction of photons of appropriate energy level with the chemical species present in the solution. The UV radiation generated radicals through photochemical degradation of homogeneous oxidizing compounds such as hydrogen peroxide, ozone or Fenton's reagent has been reported to be superior to the sole use of ultraviolet (UV) radiation or the sole use of such oxidants [53-60]. Highly absorbent UV dye wastewater can inhibit the effectiveness of the process by limiting the penetration of UV radiation, which requires the use of high- intensity UV lamps and/or a specially designed reactor. Photocatalytic mechanism occurring at the surface of the semiconductors is the other way of obtaining free radicals.. Titanium dioxide in the anatase form has reasonable photoactivity and is the most commonly used photo catalyst. It also has the advantages of being insoluble, relatively inexpensive, non- toxic, as well as having resistance to photocorrosion and biological immunity $[61,62]$. The photocatalytic process can be performed by simply using the slurry of fine catalyst particles dispersed in liquid phase in a reactor or by using supported/immobilized catalysts. The limitations of the slurry reactors include the low efficiency of radiation due to the opacity of the suspension, fouling of the surface of the radiation source due to the decomposition of the catalyst and the requirement of ultrafine catalyst particles to be separated from the treated liquid [63-68].

Besides single photocatalysis, there are also reports on the use of photocatalysis in the presence of $\mathrm{O}_{3}$ or $\mathrm{H}_{2} \mathrm{O}_{2}$ having improved bleaching and mineralization. Considering the total mineralization of compounds, the photocatalytic ozonation has specific energy consumption much lower than conventional photocatalysis and ozonation. The Fenton's reagent and its alterations, such as the thermal Fenton process or the photo- Fenton reaction using Fe (II)/ $\mathrm{Fe}$ (III) oxalate ion, $\mathrm{H}_{2} \mathrm{O}_{2}$ and UV radiation have established much consideration as a means for the whitening of synthetic dyes $[69,70]$. In the photo - Fenton technique, $\mathrm{H}_{2} \mathrm{O}_{2}$ is used swiftly in three synchronized reactions and the shortest action of Fenton, photo - reduction of $\mathrm{Fe}$ (III) ions to $\mathrm{Fe}$ (II) and $\mathrm{H}_{2} \mathrm{O}_{2}$ photolysis. Thus, this process produces more hydroxyl radicals compared with the conventional Fenton method or photolysis. Few reports suggest that in case of comparable pollutant removal performance, the Fenton process can be gainful, in conjunction with the use of advanced oxidation alternatives reducing the energy consumption, the consumption of $\mathrm{H}_{2} \mathrm{O}_{2}$, lower cost of sludge disposal, higher flexibility and lower requirement of maintenance. Fenton reagent requires the use of large amounts of acidic and alkaline chemicals $[71,72]$. In order to take advantage of Fenton oxidizing agents role in eliminating the separation of iron salts, the usage of $\mathrm{H}_{2} \mathrm{O}_{2}$ /iron powder solution system was recommended. This process can provide better stain removal than the " $\mathrm{H}_{2} \mathrm{O}_{2} / \mathrm{Fe}^{+2 "}$ due to chemisorptions of iron powder addition to the usual type of reaction (203). Though the Fenton Fenton -type reactions based on different transition metals, was less explored to date, they have been described to be insensitive to $\mathrm{pH}$ and effective for the degradation of synthetic dyes. Among the AOP, the photo-Fenton reaction and titanium dioxide $\left(\mathrm{TiO}_{2}\right)$ mediated heterogeneous photo catalytic treatment processes are proficient of absorbing the light in the near-UV spectral region for initiating the radical reactions. Their application would virtually eliminate major operating costs when solar radiation is used instead of artificial UV light. The ferrioxalate solution that has long been used as a chemical actinomètre can be used in the process of photo Fenton to derive further benefit by replacing UV light with solar radiation [73-80]. Recently, several attempts have been made to increase the photocatalytic efficiency of $\mathrm{TiO}_{2}$ that include the deposition of noble metal doping ions, addition of inorganic adsorbent, catalysts of the coupling, the use of nonporous films, and so on. In addition to this, new catalysts, such as metallo porphyrins polymers were reported to be easily excited by violet or visible light, with only $3 \%$ usage of the avaialable solar energy for the the commonly used $\mathrm{TiO}_{2}[81]$.

\section{Combination of electrochemical and photochemical process}

In the electrochemical treatment, the oxidation is carried out by means of electrodes, where determined potential difference is applied. Based on this principle, many different processes were developed as direct and indirect electrochemical processes that include cathodic and anodic oxidation, electrocoagulation, electrodialysis, electromembrane, and electrochemical ion exchange. Sometimes the combination of electrochemical technology and photocatalysis has been adopted for avail unique advantages. For example, the chemical synergy process of photocatalysis and electrochemicals can give increased discoloration and the added benefit of the removal of chemical oxygen demand that may be derived from existence of the salt in solution, which otherwise is harmful to perform sole photo catalysis [82-90]. Conversely, electroFenton process requires no addition of chemicals other than the catalytic amount of $\mathrm{Fe}^{+2}$, that is produced from $\mathrm{H}_{2} \mathrm{O}_{2}$ in situ, thereby avoiding the transportation of the dangerous oxidant. With high pulsed voltage electrical discharge process, more oxidants such as $\mathrm{H}_{2} \mathrm{O}_{2}$ give rise to highly reactive free radical species by photo-dissociation of $\mathrm{H}_{2} \mathrm{O}_{2}$ and thus improves the overall process $[91,92]$.

\section{Sonolysis process}

The use of sono chemical methods for treating a variety of chemical contaminants in an aqueous solution have been conducted in many studies. These studies mainly reported the systems and the basic theory of sonochemical reactions for environmental applications. Sonolysis is mainly based on acoustic cavitation including training, growth and implosion of bubbles in a liquid collapse as depicted in Figure 4. For detailed information of cavitation training, the readers are requested to refer to previous references. The positive and negative pressures are exerted on a liquid, by the compression and expansion of ultrasonic wave cycles, respectively [93-100]. When the negative pressure applied on the liquid is sufficiently high, the average distance between the molecules would exceed the critical molecular distance necessary to maintain the intact liquid and the liquid will break down to form cavities in vapor and gas-filled micro bubbles. The gases and vapors are compressed inside the heat generating cavity which ultimately produces a localized hot spot of short duration, creating local pressures and high temperatures [101-103]. Among the sonochimie theories, the hot spot theory is widely accepted to explain the sonochemical reactions in the field of environment, which suggests that the collapse is so rapid and that the compression of the gas and steam inside the bubble is an adiabatic process. Ultrasonic energy affects chemical reactions releasing enormous heat or production of reactive free radicals, there by increasing the mass transfer rate in an aqueous solution through turbulence. Inside the cavitation the breakdown of the water molecules to bubbles forming pyrolysis $\mathrm{OH}$ - and $\mathrm{H}$. radicals in the gas phase of the reaction [104-106]. The substrate reacts with either $\cdot \mathrm{OH}$ or undergoes pyrolysis. In the interface region, a similar reaction occurs but in an 


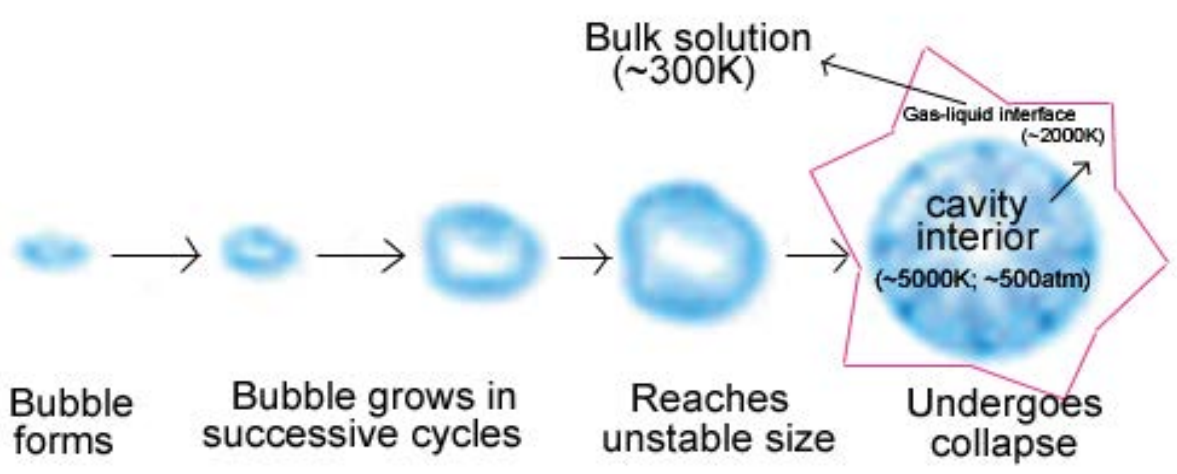

Figure 4: The formation and collapse of a cavitation bubble, and three reaction zones in the cavitation process.

aqueous phase, the $\cdot \mathrm{OH}$ radicals recombine to form $\mathrm{H}_{2} \mathrm{O}_{2}$. In bulk solution, a small number of free radicals produced from the cavities or the interface can move to the liquid phase in the mass, and the reactions are essentially between the substrate and $\cdot \mathrm{OH}$ and $\mathrm{H}_{2} \mathrm{O}_{2}$ [107].

$$
\begin{gathered}
\mathrm{H}_{2} \mathrm{O} \rightarrow \cdot \mathrm{OH}+\cdot \mathrm{H} \\
\cdot \mathrm{OH}+\cdot \mathrm{OH} \rightarrow \mathrm{H}_{2} \mathrm{O}_{2}, \quad k=5.5 \times 10^{9} \mathrm{M}^{-1} \mathrm{~S}^{-1}
\end{gathered}
$$

\section{Physico-chemical process combination with advanced oxidation process}

Coagulation based combinations: Many studies have examined different combinations of physicochemical systems for textile processing and dyeing wastewater. The combinations of classical physicochemical and AOP techniques have thus emerged as an attractive option. Flocculation/coagulation precipitation methods have been extensively used for decolorizing dye containing industrial wastewater [107-110]. For pretreatment of raw wastewater before discharging to public capital processing factories, these processes may be satisfactory with respect to the reduction of the chemical oxygen demand, and partial discoloration. Their standalone application in the treatment of textile waste/dye is however relatively ineffective; for example, only $50 \%$ of the removal was performed using either alum or ferrous sulfate to a yellow azo dye reagent. In the coagulation process, it is difficult to remove the highly soluble dyes in water, and more importantly, this process produces large amount of sludge. However, the researchers are persistent in their pursuit to minimize the limitations of this technology. For example, polyaluminium ferric chloride, a new type of composite coagulant, was reported to have the advantages of high stability and good coagulating effect of hydrophobic and hydrophilic dyes. The discoloration capacity exceeded that of the poly polyferric sulfate and aluminum chloride. On the other hand, to avoid any problem of the disposal of solid sludge, different innovative approaches have been proposed. These include clotting separate volume low dye bath alum sludge recycling, recovery of chemical coagulant textile sludge, reuse of sludge in textile building materials, and processes such as vermicomposting textile mill sludge, coagulation followed by carbon adsorption. The coagulation followed by adsorption has been reported to produce effluent reuse standard compared with the shoot coagulant consumption by $50 \%$, thereby lowering the formed sludge volume compared to induce coagulation alone [111-115]. Coagulation in combination with AOP, whether sequential or simultaneously, has been reported for dyeing wastewater. For example, simultaneous application of coagulation and Fenton oxidation showed improved performance over one of their autonomous applications. Chemical coagulation of fenton after treatment was found to reduce floc-settling time, improvement in the discoloration and in the reduction of the soluble iron effluent. Conversely photo-Fenton subsequent to coagulation process was reported to finish fading and produce better DCO, with the added benefit of reducing the load on the AOP thus reducing the chemical usage. The studies in the sequential use of coagulation and ozonation revealed the superiority of this arrangement preceded by ozonation coagulation. Reverse multistage coagulation followed by ozonation was shown to be superior to their sequential application of single pass. The advantages of this application in several steps was more convincing if the wastewater is with recalcitrant composition [116-120].

Adsorption: Adsorption techniques are especially used for the bleaching of dyes in industrial effluents. The activated carbon, either in the powder or granular form is the most widely used adsorbent due to its extensive surface micro porous structure, high adsorption capacity and high surface reactivity. It is very effective to adsorb cationic, mordant and acid dyes and to a lesser extent dispersed, direct, vat, pigment and reactive dyes. The use of carbon adsorption for decolorization of the crude wastewater is impractical as a consequence of the competition between the colored molecules, and other organic/ inorganic compounds. Hence, its use is recommended as a polishing step or used at the end of an emergency unit treatment stage to meet the discharge color duration. The weight loss is inevitable during its expensive onsite regeneration and hampers its widespread use. The use of non-conventional, economical sources as precursors for activated carbon has been proposed to achieve the cost-effectiveness in the application. As previously stated, adsorption is a non-destructive method in which there is only the change in the phase of the removed impurities and, therefore impose further problems in the form of sludge [121-124]. The high cost also necessitates the adsorbent regeneration. On the contrary, some catalytic oxidation /reduction systems seem to be more effectively focused on the treatment of the small volume dyes. So it seems attractive to combine other adsorption process in a system where the contaminants are pre-concentrated on the absorbent, and then separated from the water. The thus separated contaminants can subsequently be mineralized (example wet air oxidation) or degraded to a certain extent (example, azo bond reduction with bisulfite mediated borohydride to regenerate the adsorbent and re-use). In this manner, an economic process can be developed linking two processing techniques that can eliminate their inherent disadvantages. The application of partial degradation to regenerate the adsorbent leaves behind a small amount of wastewater to treat. Again, this can be easily taken care of by the application of some AOP. Adsorption simultaneously with 
ozonation, $\mathrm{UV}-\mathrm{H}_{2} \mathrm{O}_{2}$ or microwave has induced oxidation. The mutual reported improvements such as catalysis of AOP yield by adsorbent and simultaneous regeneration of adsorbent. A rather complicated method involving solvent extraction and catalytic oxidation has been documented in the literature. This method involves dye extraction by means of an economical solvent, followed by recovery with dye chemical stripping [125-127].

Combination with membrane technology: Membrane separation gives the possibilities of either the concentration of the dyes and adjuvants and producing purified water, or the removal of the dye and allowing the re-use of water along with extra chemicals, or even the realization of the recovery of the substantial part of the dye, admixtures and water all together [128]. This recovery/reuse practice reduces many folds the recurring costs for the treatment of waste streams. The fact that the behavior of the paint residual dye ideally identical to that of the fresh dye may restrict recovery and the re-use of specific dye classes. Accordingly, water and/or electrolytic recovery of dye bath effluent have become the focus of contemporary literature [129]. However, the production of concentrated sludge and the occurrence of frequent membrane fouling that involves expensive membrane replacement hinder the widespread use of this technology. Two different trends are so evident among the reported studies that link the membrane separation and other technologies. Some studies focused on the reduction of the membrane concentrated disposal problem, while others concentrated on the full-hybrid systems, which might eliminate the limitations of the membrane technology, and/or that of the counterpart technologies $[130,131]$.

Hybrid processes based on membrane and photocatalysis were reported to eradicate the problem of the ultrafine catalyst to be separated from the treated liquid in the case of slurry reactors. Further they also have the added advantage of the membrane acting as a selective barrier for the species to be degraded. In case of immobilized catalysis, the membrane may play a role in connecting the photocatalyst with photocatalysis and membrane distillation. However it was reported to be more advantageous compared with the pressure-driven membrane process, because it may be associated with significant fouling. It is proposed that the pretreatment of photo- oxidation $\left(\mathrm{UV} / \mathrm{TiO}_{2} / \mathrm{H}_{2} \mathrm{O}_{2}\right)$ before membrane filtration to partially decompose high molecular weight compounds that cause fouling of the membrane. The relatively smaller fragments that were produced were still retainable within the membrane, and unlike the parent compound does not affect the charge of the membrane surface [132]. The membrane contactors encompass mass transfer by diffusion through the pores and offer advantages for higher contact area. They involve lower cost and help in the easy scaleup process without foam formation [133].

\section{Combination with biological treatment}

Combination among biological process: A conventional chemical coagulation step that is preceded by or antecedent to biological treatment is applied in the treatment of dye wastewater. This is also combined with municipal wastewater treatment and usually favored wherever applicable [134]. Various biological processes such as activated sludge, liquid biofilm, different solid film systems or combinations thereof have been applied. Although aerobic bacteria mediated co-metabolic reductive cleavage of azo dyes and use of azo compounds as sole source of carbon and energy has been reported, the dyes are generally very resistant to degradation under aerobic conditions. The toxicity of the dye waste water and the factors inhibiting the permeation of the dye by the microbial cell membrane reduces the effectiveness of the biological degradation. A combined treatment of anaerobic-aerobic system of azo dye appears to be attractive as the azo bond reduction can be performed under reducing conditions in anaerobic bioreactors and colorless aromatic amines thus obtained can be mineralized in aerobic conditions [133]. The biotic process, dominates high rate anaerobic bioreactors. The addition of anthraquinone compounds such as redox mediator sulfonate, di-anthraquinone sulfonate were reported to greatly enhance both biotic and abiotic processes. After anaerobic treatment, the post-treatment of the azo dye containing encompasses competition between the biodegradation and auto oxidation of aromatic amines. The biological therapy is a competitive and environmentally friendly alternative [134]. The researchers are therefore persevering their efforts to minimize the inherent limitations of biological dye wastewater treatment. There are several innovative attempts that have been tried and documented in the literature to achieve a better design of the reactor and/or use of the special dye-degrading microorganisms for integrated textile manufacturing wastewater treatment. Some of these innovative efforts include- two stages activated sludge process; highrate anaerobic systems disconnect the hydraulic retention time of the solids retention time [135].

\section{Hybrid biological process}

Physico-chemical and biological treatment: As mentioned above, the literature is replete with examples of using the additional coagulation organic discoloration. The choice between the coagulation - biological or biological-coagulation system depends on the type and dosage of the coagulant, the amount of sludge, and the degree of inhibitory and nonbiodegradable substances in the wastewater [136]. Coagulation before biological treatment may be advantageous for the alkaline wastewater. After biological treatment, the ferrous sulfate treatment cannot be used as the $\mathrm{pH}$ becomes close to neutral. On the other hand, the dose of coagulants and the amount of the bio-sludge after chemical treatment are smaller compared to those of the coagulation followed biological treatment [137]. Besides coagulation, a variety of other treatments can be combined with a biological treatment. Very often certain physicochemical process is located before and /or after AOP. The biological method is either applied as a penultimate or the last treatment unit. Given the abundance of the bio resistant toxic substances in wastewater dyes, the physico-chemical pre-treatment and advanced oxidation before biological treatment seems to be a rational choice. The choice between the physico-chemical and oxidative pretreatment depends on the specific wastewater and, usually bright-stream separation would facilitate the application of appropriate treatment or different streams [138].

Biodegradation: The conventional pre or post treatment concepts includes the the design process containing individual components that are independent of each other. In contrast to this, a more innovative "integrated- process" approach was developed which combined the efficacy of the biological and other treatments that are synergistic in their effect [139]. A typical example of this processes is the advanced of an activated sludge treatment where chemical oxidation was specifically designed to partially degrade recalcitrant contaminants to readily biodegradable intermediates. In the recent years, the studies that dealt with the partial pre-oxidation of myriads of dye wastewater reported the involvement of all kinds of PDO. Some of these studies included the partial oxidation ozonation, $\mathrm{H}_{2} \mathrm{O}_{2}$ photocatalysis, photography -Fenton moist air oxidation combined with photocatalysis and ozonation $/ \mathrm{H}_{2} \mathrm{O}_{2}$, photo-electrochemical process [6] under oxidation, and water and supercritical electron beam bulk of treatment [140]. These studies reported on the improvement of the biodegradability and the reduction of toxicity following PDO treatment without the biological reactor. However, the complete results were not obtained. The combined oxidation and subsequent biodegradation make it 
Citation: Shah MP (2016) Industrial Wastewater Treatment: A Challenging Task in the Industrial Waste Management. Adv Recycling Waste Manag 2: 115. DOI: $10.4172 / 2475-7675.1000115$

Page 8 of 11

necessary to adjust the optimum oxidation treatment point. Further the oxidation cannot lead to significant changes in the molecular weight distribution, but resulted in the increase of thelow molecular weight mineralization substances. Therefore, the rationale is to adopt the shortest possible preoxidizing period and remove the biodegradable fraction using organic profitable process. However, the degree of COD removal obtained from combining with this strategy can be limited in some cases, making the use of an oxidation period [141]. An internal biological process between oxidation and recycling biological step has been recommended to reduce the dose of the chemicals in such circumstances. If there are considerable amount of biodegradable compounds that initially exist in the wastewater, the pre-oxidation step does not lead to a significant improvement in the biodegradability but rather cause unnecessary consumption of chemicals. In such cases the biological pre-treatment is followed by a PDO, and biological polishing step, can be more useful [142].

Adsorption with biodegradation: Conventional biological treatments have limited effectiveness in the treatment of rebellious textiles wastewater that is mostly composed of recalcitrant chemicals. Due to this reason the textile dyes, various adsorbents and chemicals that predominantly include the activated carbon were directly added to the activated sewage systems in some studies [143]. The fact that the additional removal of soluble organic substances (chemical oxygen demand and and total organic carbon), in such a system compared to the conventional system cannot explain the likely contribution of adsorbent as it was predicted that the adsorption isotherms assume a synergistic relationship between the activated carbon and microorganism [144]. Enhanced biodegradation was attributed to the ability of the adsorbent that acts as a modulator by immediately adsorbing the high concentrations of toxic substances, thereby managing the free concentration of toxic substances. This provides an enriched environment for the microbial metabolism that takes place at the liquid-solid surface onto which the microbial cells, enzymes, organic materials and oxygen are adsorbed [145]. The main step in dye removal for activated carbon amended biological process is microbial degradation, which is higher than the adsorption on both activated carbon as well as on biomass [146-155].

Membrane bioreactors: A membrane bioreactor exhibits more improvement over conventional activated sludge treatment, and was shown to be promising in the color treatment of wastewater [156]. For discoloration, a membrane bioreactor for is frequently introduced in conjunction with the charcoal amended digester that involves the current adsorption scheme of treatment. This is preceded by the aerobic membrane bioreactor that comprehends stable discoloration together with the elimination of high total organic carbon. Rarely the membrane bioreactors were used as major treatment process before the polishing of the nano filtration step or in the complicated treatments that include anaerobic/aerobic pretreatment before membrane bioreactor ozonation [157]. The current literature includes an innovative approach of using the membrane separated fungus reactor which helps in the excellent degradation ability of white-mold $[158,159]$.

\section{References}

1. Abadulla E, Tzanov T, Costa S, Robra KH, Cavaco PA, et al. (2000) Decolorization and detoxification of textile dyes with a laccase from Trametes hirsuta. Appl Environ Microbiol 66: 3357-3362.

2. Akan JC, Abdulrahman FI, Ayodele JT, Ogugbuaja VO (2009) Impact of tannery and textile effluent on the chemical characteristics of Challawa River, Kano State Nigeria. Aust J Basic Appl Sci 3: 1933-1947.

3. Albuquerque MGE, Lopes AT, Serralheiro ML, Novais JM, Pinheiro HM (2005) Biological sulphate reduction and redox mediator effects on azo dye decolourisation in anaerobic-aerobic sequencing batch reactors. Enzyme Microbiol Technol 36: 790-799.

4. Aleboyeh A, Aleboyeh $\mathrm{H}$, Moussa $Y$ (2003) Critical" effect of hydrogen peroxide in photochemical oxidative decolorization of dyes: Acid Orange 8, Acid Blue 74 and Methyl Orange. Dyes and Pigments 57: 67.

5. Ali N, Hameed A, Siddiqui MF, Ghumro PB, Ahmed S (2009) Application of Aspergillus niger SA1 for the enhanced bioremoval of azo dyes in simulated textile effluent. Afr J Biotechnol 8: 3839-3845.

6. An TC, Zhu XH, Xiong Y (2002) Feasibility study of photoelectrochemical degradation of methylene blue with three-dimensional electrode-photocatalytic reactor. Chemosphere 46: 897.

7. Anastasi A, Parato B, Spina F, Tigini V, Prigione V, et al. (2011) Decolourisation and detoxification in the fungal treatment of textile wastewaters from dyeing processes. New Biotechnol 29: 38-45.

8. Ang EL, Zhao H, Obbard JP (2005) Recent advances in the bioremediation of persistent organic pollutants via biomolecular engineering. Enzyme Microbiol Technol 37: 487-496.

9. Anjaneya O, Souche SY, Santoshkumar M, Karegoudar TB (2011) Decolorization of sulfonated azo dye Metanil Yellow by newly isolated bacterial strains: Bacillus sp. strain AK1 and Lysinibacillus sp. strain AK2. J Hazard Mater 190: 351-358.

10. APHA (1998) Standard Methods for the Examination of Water and Wastewater 20th edn. American Public Health Association, Washington, DC.

11. Arslan I, Balcioglu IA Bahnemann DW (2000) Advanced chemical oxidation of reactive dyes in simulated dyehouse effluents by ferrioxalate-Fenton/UV-A and $\mathrm{TiO}_{2} /$ UV-A processes. Dyes and Pigments 47: 207.

12. Asgher M, Azim N, Bhatti HN (2009) Decolorization of practical textile industry effluents by white rot fungus Coriolus versicolor IBL-04. Biochem Eng J 47: 61-5.

13. Ayed L, Mahdhi A, Cheref A, Bakhrouf A (2011) Decolorization and degradation of azo dye Methyl Red by an isolated Sphingomonas paucimobilis: biotoxicity and metabolites characterization. Desalination 274: 272-277.

14. Babel S, Kurniwan TA (2003) Low-cost adsorbents for heavy metals uptake from contaminated water: a review. Journal of Hazardous Materials 97: 219.

15. Babu BR, Parande AK, Raghu S, Kumar TP (2007) Cotton textile processing: waste generation and effluent treatment. J Cotton Sci 11: 141-53.

16. Bandara J, Morrison C, Kiwi J, Pulgarin C, Peringer P (1996) Degradation/ decoloration of concentrated solutions of Orange II. Kinetics and quantum yield for sunlight induced reactions via Fenton type reagents. J Photochem Photobio A: Chem. 99: 57.

17. Baughman GL, Weber EJ (1994) Transformation of dyes and related compounds in anoxic sediment: kinetic and products. Environ Sci Technol 28 267-276.

18. Beydilli MI, Pavlostathis SG, Tincher WC (1998) Decolorization and toxicity screening of selected reactive azo dyes under methanogenic conditions. Water Sci Technol 38: 225-232

19. Blumel S, Stolz A (2003) Cloning and characterization of the gene coding for the aerobic azoreductase from Pigmentiphaga kullae k24. Appl Microbio Biotechnol 62: 186-190.

20. Bohmer U, Kirsten C, Bley T, Noack M (2010) White-rot fungi combined with lignite granules and lignitic xylite to decolorize textile industry wastewater. Eng Life Sci 10: 26-34.

21. Bragger JL, Lloyd AW, Soozandehfar SH, Bloomfield SF, Marriott C, et al. (1997) Investigations into the azo reducing activity of a common colonic microorganism. Int J Pharm 157: 61-71.

22. Bromley-Challenor KCA, Knapp JS, Zhang Z, Gray NCC, Hetheridge MJ, et al. (2000) Decolorization of an azo dye by unacclimated activated sludge under anaerobic conditions. Water Res 34: 4410-4418.

23. Brown JP (1981) Reduction of polymeric azo and nitro dyes by intestinal bacteria. Appl Environ Microbiol 41: 1283-1286.

24. Carita R, Marin-Morales MA (2008) Induction of chromosome aberrations in the Allium cepa test system caused by the exposure of seeds to industrial effluents contaminated with azo dyes. Chemosphere 72: 722-725.

25. Casieri L, Varese GC, Anastasi A, Prigione V, Svobodova K, et al. (2008) 
Citation: Shah MP (2016) Industrial Wastewater Treatment: A Challenging Task in the Industrial Waste Management. Adv Recycling Waste Manag 2: 115. DOI: 10.4172/2475-7675.1000115

Decoloration and detoxification of reactive industrial dyes by immobilized fung Trametes pubescens and Pleurotus ostreatus. Folia Microbiol 53: 44-52.

26. Cervantes FJ (2002) Quinones as Electron Acceptors and Redox Mediators for the Anaerobic Biotransformation of Priority Pollutants. Agrotechnology and Food Sciences, Sub-department of Environmental Technology, Wageningen University, Wageningen, The Netherlands pp: 166.

27. Charumathi D, Nilanjana D (2010) Bioaccumulation of synthetic dyes by Candida tropicalis growing in sugarcane bagasse extract medium. Adv Bio Res 4: 233-240.

28. Chen BY, Hsueh $\mathrm{CH}$, Chen WM, Li WD (2011) Exploring decolorization and halotolerance characteristics by indigenousacclimatized bacteria: chemical structure of azo dyes and dose-response assessment. J Taiwan Inst Chem Eng 42: 816-825

29. Chen G (2004) Electrochemical technologies in wastewater treatment Separation and Purification Technology 38: 11

30. Chen H, Wang RF, Cerniglia CE (2004) Molecular cloning, overexpression, purification, and characterization of an aerobic FMN-dependent azoreductase from Enterococcus faecalis. Protein Express Purif 34: 302-310.

31. Chivukula M, Renganathan V (1995) Phenolic azo dye oxidation by laccase from Pyricularia oryzae. Appl Environ Microbiol 61: 4374-4377.

32. Chung KT, Stevens SEJ (1993) Degradation of azo dyes by environmenta microorganisms and helminths. Environ Toxicol Chem 12: 2121-2132.

33. Chung KT, Stevens SEJ, Cerniglia CE (1992) The reduction of azo dyes by the intestinal microflora. Crit Rev Microbiol 18: 175-197.

34. Claus H, Faber G, Koenig H (2002) Redox-mediated decolorization of synthetic dyes by fungal laccases. Appl Microbiol Biotechnol 59: 672-678.

35. Das D, Charumathi D, Das N (2010) Combined effects of sugarcane bagasse extract and synthetic dyes on the growth and bioaccumulation properties of Pichia fermentans MTCC 189. J Hazard Mater 183: 497-505.

36. Dawkar VV, Jadhav UU, Govindwar SP (2009) Effect of inducers on the Decolorization and biodegradation of textile azo dye Navy blue $2 \mathrm{GL}$ by Bacillus sp. VUS. Biodegradation 20: 777-787.

37. Dos Santos AB (2005) Reductive Decolourisation of Dyes by Thermophilic Anaerobic Granular Sludge. Sub-department of Environmental Technology, Wageningen University, Wageningen, pp: 176

38. Dos Santos AB, Bisschops IAE, Cervantes FJ, Van Lier JB (2004) Effect of different redox mediators during thermophilic azo dye reduction by anaerobic granular sludge and comparative study between mesophilic $\left(30^{\circ} \mathrm{C}\right)$ and thermophilic $\left(55^{\circ} \mathrm{C}\right)$ treatments for decolourisation of textile wastewaters. Chemosphere 55: 1149-1157.

39. Dos Santos AB, Cervantes FJ, Van Lier JB (2004) Azo dye reduction by thermophilic anaerobic granular sludge, and the impact of the redox mediator AQDS on the reductive biochemical transformation. Appl Microbiol Biotechno 64: 62-69.

40. Dua M, Singh A, Sethunathan N, Johri AK (2002) Biotechnology and bioremediation: successes and limitations. Appl Microbiol Biotechnol 59: 143-152.

41. Dubin P, Wright KL (1975) Reduction of azo food dyes in cultures of Proteus vulgaris. Xenobiotica 5: 563-571.

42. Dunnivant FM, Schwarzenbach RP, Macalady DL (1992) Reduction of substituted nitrobenzenes in aqueous solutions containing natural organic matter. Environ Sci Technol 26: 2133-2141.

43. Duran N, Rosa MA, D'Annibale A, Gianfreda L (2002) Applications of laccases and tyrosinases (phenoloxidases) immobilized on different supports: a review. Enzyme Microbiol Technol 31: 907-931.

44. Elisangela F, rea Z, Fabio DG, Cristiano RM, Regina DL, Artur CP (2009) Biodegradation of textile azo dyes by a facultative Staphylococcus arlettae strain VN-11 using a sequential microaerophilic/aerobic process. Int Biodeter Biodegr 63: 280-288.

45. El-Sheekh MM, Gharieb MM, Abou-El-Souod GW (2009) Biodegradation of dyes by some green algae and cyanobacteria. Int Biodeter Biodegr 63: 699704.

46. Enayatizamir N, Tabandeh F, Rodrǐıguez Couto S, Yakhchali B, Alikhan $\mathrm{HA}$, et al. (2011) Biodegradation pathway and detoxification of the diazo dye Reactive Black 5 by Phanerochaete chrysosporium. Bioresour Technol 102: 10359-10362.
47. Encinas Yocupicio AA, Razo-Flores E, Sanchez Diaz F, Dos Santos AB, Field JA, et al. (2006) Catalytic effects of different redox mediators on the reductive decolorization of azo dyes. Water Sci Technol 54: 165-170.

48. Erden E, Kaymaz Y, Pazarlioglu NK (2011) Biosorption kinetics of a direct azo dye Sirius Blue K-CFN by Trametes versicolor. Electron J Biotechnol 14: 1-10.

49. Faryal R, Hameed A (2005) Isolation and characterization of various fungal strains from textile effluent for their use in bioremediation. Pak J Bot 37: 1003-1008.

50. Fernandez JA, Henao LM, Pedroza-Rodriguez AM, Quevedo-Hidalgo B (2009) Immobilising lignilolytic fungus for removing Reactive Black 5 dye. Rev Colomb Biotecnol. 11: 59-72.

51. Ferraz ERA, Umbuzeiro GA, de-Almeida G, Caloto-Oliveira A, Chequer FMD et al. (2011) Differential toxicity of disperse Red 1 and disperse Red 13 in the ames test HepG2 cytotoxicity assay and Daphnia Acute toxicity test. Environ Toxicol 26: 489-497.

52. Field JA, Brady J (2003) Riboflavin as a redox mediator accelerating the reduction of the azo dye Mordant Yellow 10 by anaerobic granular sludge. Water Sci Technol 48: 187-193.

53. Field JA, Stams AJM, Kato M, Schraa G (1995) Enhanced biodegradation of aromatic pollutants in cocultures of anaerobic and aerobic bacterial consortia. Antonie van Leeuwenhoek 67: 47-77.

54. Forgacs E, Cserháti T, Oros G (2004) Removal of synthetic dyes from wastewaters: a review. Environment International 30: 953.

55. Fu Y, Viraraghavan T (2001) Fungal decolorization of dye wastewaters: review. Bioresource Technology 79: 251.

56. Garcia-Montano J, Domenech X, Garcia HA, Torrades F, Peral J (2008) The testing of several biological and chemical coupled treatments for Cibacron Red FN-R azo dye removal. J Hazard Mater 154: 484-490.

57. Gingell R, Walker R (1971) Mechanism of azo reduction by Streptococcus faecalis II. The role of soluble flavins. Xenobiotica 1: 231-239.

58. Glenn JK, Akileswaran L, Gold MH (1986) Manganese-li oxidation is the principal function of the extracellular manganese peroxidase from Phanerochaete chrysosporium. Arch Biochem Biophys 251: 688-696.

59. Gogate PR, Pandit AB (2004) A review of imperative technologies for wastewater treatment II: hybrid methods. Advances in Environmental Research 8: 553.

60. Gogate PR, Pandit AB (2004) A review of imperative technologies for wastewater treatment I: oxidation technologies at ambient conditions. Advances in Environmental Research 8: 501.

61. Gonzalez-Gutierrez LV, Escamilla-Silva EM (2009) Reactive red azo dye degradation in a UASB bioreactor: mechanism and kinetics. Eng Life Sci 9 311-316.

62. Guivarch E, Trevin S, Lahitte, C, Oturan MA (2003) Degradation of azo dyes in water by Electro-Fenton process. Environ Chem Lett 1: 38.

63. Gujer W, Zehnder AJB (1983) Conversion processes in anaerobic digestion. Water Sci Technol 15: 127-167.

64. Gürses A, Yalçin M, Dogar C (2002) Electrocoagulation of some reactive dyes: a statistical investigation of some electrochemical variables. Waste Management 22: 491.

65. Hao OJ, Kim H, Chang PC (2000) Decolorization of wastewater. Crit Rev Env Sci Technol 30: 449-505.

66. Heinfling A, Bergbauer M, Szewzyk U (1997) Biodegradation of azo and phthalocyanine dyes by Trametes versicolor and Bjerkandera adusta. App Microbiol Biotechnol 48: 261-266.

67. Hsu Y-C, Yen C-H, Huang H-C (1998) Multistage treatment of high strength dye wastewater by coagulation and ozonation. J Chem Technol Biotechnol 71: 71-76.

68. Hsueh CC, Chen BY, Yen CY (2009) Understanding effects of chemical structure on azo dye decolorization characteristics by Aeromonas hydrophila. J Hazard Mater 167: 995-1001.

69. Hu H, Yang M, Dang J (2005) Treatment of strong acid dye wastewater by solvent extraction. Separation and Purification Technology 42: 129.

70. Ince NH, Hasan DA, Üstün B, Tezcanli G (2002) Combinative dyebath treatment with activated carbon and UV/H2O2: a case study on Everzol BlackGSP®. Wat sci Tech 46: 51.

71. Jadhav JP, Parshetti GK, Kalme SD, Govindwar SP (2007) Decolourization of 
Citation: Shah MP (2016) Industrial Wastewater Treatment: A Challenging Task in the Industrial Waste Management. Adv Recycling Waste Manag 2: 115 . DOI: $10.4172 / 2475-7675.1000115$

Page 10 of 11

azo dye Methyl Red by Saccharomyces cerevisiae MTCC 463. Chemosphere 68: $394-400$

72. Jadhav SB, Phugare SS, Patil PS, Jadhav JP (2011) Biochemical degradation pathway of textile dye Remazol Red and subsequent toxicological evaluation by cytotoxicity, genotoxicity and oxidative stress studies. Int Biodeter Biodegr 65: 733-743

73. Jadhav SU, Jadhav MU, Kagalkar AN, Govindwar SP (2008) Decolorization of Brilliant Blue $G$ dye mediated by degradation of the microbial consortium of Galactomyces geotrichum and Bacillus sp J Chin Inst Chem Eng 39: 563-70.

74. Jin XC, Liu GQ, Xu ZH, Tao WY (2007) Decolorization of a dye industry effluent by Aspergillus fumigatus XC6. Appl Microbiol Biotechnol 74: 239-243.

75. Jonstrup M, Punzi M, Mattiasson B (2011) Comparison of anaerobic pretreatment and aerobic post-treatment coupled to photo-Fenton oxidation for degradation of azo dyes. J Photoch Photobio A: Chem 224: 55-61.

76. Keck A, Klein J, Kudlich M, Stolz A, Knackmuss HJ, Mattes R (1997) Reduction of azo dyes by redox mediators originating in the naphthalenesulfonic acid degradation pathway of Sphingomonas sp. strain BN6. Appl Environ Microbiol 63: $3684-3690$

77. Keck A, Rau J, Reemtsma T, Mattes R, Stolz A, et al. (2002) Identification of quinoide redox mediators that are formed during the degradation of naphthalene-2-sulfonate by Sphingomonas xenophaga BN6. Appl Environ Microbiol 68: 4341-4349.

78. Khelifi E, Ayed L, Bouallagui H, Touhami Y, Hamdi M (2009) Effect of nitrogen and carbon sources on Indigo and Congo red decolourization by Aspergillus alliaceus strain 121C. J Hazard Mater 163: 1056-1062.

79. Khouni I, Marrot B, Amar RB (2012) Treatment of reconstituted textile wastewater containing a reactive dye in an aerobic sequencing batch reactor using a novel bacterial consortium. Sep Purif Technol 87: 110-119.

80. Knackmuss HJ (1996) Basic knowledge and perspectives of bio elimination of xenobiotic compounds. J Biotechnol 51: 287-295.

81. Konstantinous IK, Albanis TA (2004) $\mathrm{TiO}_{2}$-assisted photocatalytic degradation of azo dyes in aqueous solution: kinetic and mechanistic investigations: $A$ review. Applied Catalysis B: Environmental 49: 41.

82. Kuberan T, Anburaj J, Sundaravadivelan C, Kumar P (2011) Biodegradation of azo dye by Listeria sp. Int J Environ Sci 1: 1760-1770.

83. Kudlich M, Keck A, Klein J, Stolz A (1997) Localization of the enzyme system involves in anaerobic reduction of azo dyes by Sphingomonas sp. strain BN6 and effect of artificial redox mediators on the rate of azo dye reduction. Appl Environ Microbiol 63: 3691-3694.

84. Kumar VV, Sathyaselvabala V, Premkumar MP, Vidyadevi T, Sivanesan S (2012) Biochemical characterization of three phase portioned laccase and its application in decoloration and degradation of synthetic dyes. J Mol Catal B: Enzym. 74: 63-72.

85. Kurade MB, Waghmode TR, Govindwar SP (2011) Preferential biodegradation of structurally dissimilar dyes from a mixture by Brevibacillus laterosporus. $J$ Hazard Mater 192: 1746-1755.

86. Laszlo JA (2000) Regeneration of azo-dye-saturated cellulosic anion exchange resin by Burholderia cepacia anaerobic dye reduction. Environ Sci Technol 34: 164-172.

87. Levin L, Melignani E, Ramos AM (2010) Effect of nitrogen sources and vitamins on ligninolytic enzyme production by some white-rot fungi. Dye Decolorization by selected culture filtrates. Bioresour Technol 101: 4554-4563.

88. Li K, Xu F, Eriksson KEL (1999) Comparison of fungal laccases and redox mediators in oxidation of a nonphenolic lignin model compound. Appl Environ Microbiol 65: 2654-2660.

89. Lin SH, Lai CL (2000) Kinetic characteristics of textile wastewater ozonation in fluidized and fixed activated carbon beds. Wat res 34: 763 .

90. Lovley DR, Fraga JL, BluntHarris EL, Hayes LA, Phillips EJP, et al. (1998) Humic substances as a mediator for microbially catalyzed metal reduction. Acta Hydroch Hydrob 26: 152-157.

91. Machado KMG, Compart LCA, Morais RO, Rosa LH, Santos MH (2006) Biodegradation of reactive textile dyes by basidiomycetous fungi from Brazilian ecosystems. Braz J Microbiol 37: 481-487.

92. Madigan MT, Martinko JM, Parker J (2003) Brock Biology of Microorganisms. 10th edn. Prentice-Hall Inc., Simon \& Schuster/A Viacom Company, Upper
Saddle River, New Jersey, USA.

93. Malik PK (2003) Use of activated carbons prepared from sawdust and rice-husk for adsorption of acid dyes: a case study of Acid Yellow 36. Dyes and Pigments 56: 239.

94. Mansour HB, Ayed-Ajmi Y, Mosrati R, Corroler D, Ghedira K, et al. (2010) Acid violet 7 and its biodegradation products induce chromosome aberrations, lipid peroxidation and cholinesterase inhibition in mouse bone marrow. Environ Sci Pollut Res Int 17: 1371-1378.

95. Marechal AML, Slokar YM, Taufer T (1997) Decoloration of chlorotriazine reactive azo dyes with H2O2/UV. Dyes and Pigments 33: 281.

96. Martorell MM, Pajot HF, de Figueroa LIC (2012) Dye-decolourizing yeasts isolated from Las Yungas rainforest Dye assimilation and removal used as selection criteria. Int Biodeter Biodegr 266: 25-32.

97. Megharaj M, Ramakrishnan B, Venkateswarlu K, Sethunathan N, Naidu R (2011) Bioremediation approaches for organic pollutants: a critical perspective. Environ Int 37: 1362-1375.

98. Meng X, Liu G, Zhou J, Fu QS, Wanga G (2012) Azo dye decolorization by Shewanella aquimarina under saline conditions. Bioresour Technol 114: 95101.

99. Moir D, Masson S, Chu I (2001) Structure-activity relationship study on the bioreduction of azo dyes by Clostridium paraputrificum. Environ Toxicol Chem 20: 479-484.

100. Munari FM, Gaio TA, Calloni R, Dillon AJP (2008) Decolorization of textile dyes by enzymatic extract and submerged cultures of Pleurotus sajor-caju. World J Microbiol Biotechnol 24: 1383-1392.

101. Muthuraman G, Palanivelu K (2005) Selective extraction and separation of textile anionic dyes from aqueous solution by tetrabutyl ammonium bromide. Dyes and pigments 64: 251 .

102. Naim MM, Abd YME (2002) Removal and recovery of dyestuffs from dyeing wastewaters. Separation and Purification Methods 31: 171.

103. Neamtu M, Siminiceanu I, Yediler A, Kettrup A (2002) Kinetics of Decolorization and mineralization of reactive azo dyes in aqueous solution by the $U V / \mathrm{H}_{2} \mathrm{O}_{2}$ oxidation. Dyes and Pigments 53: 93.

104. Neyens E, Baeyens J (2003) A review of classic Fenton's peroxidation as an advanced oxidation technique. J Hazardous Materials B98: 33.

105. O'Loughlin EJ, Burris DR, Delcomyn CA (1999) Reductive dechlorination of trichloroethene mediated by humic-metal complexes. Environ Sci Technol 33: 1145-1147.

106. Ola IO, Akintokun AK, Akpan I, Omomowo IO, Areo VO (2010) Aerobic decolourization of two reactive azo dyes under varying carbon and nitrogen source by Bacillus cereus. Afr J Biotechnol 9: 672-677.

107. Olukanni OD, Osuntoki AA, Gbenle GO (2009) Decolourizatioin of azo dyes by a strain of Micrococcus isolated from a refuse dump soil. Biotechnology 8 : $442-448$

108. Omar $\mathrm{HH}$ (2008) Algal decolorization and degradation of monoazo and diazo dyes. Pak J Biol Sci 11: 1310-1316.

109. Oturkar CC, Nemade HN, Mulik PM, Patole MS, Hawaldar RR, et al. (2011) Mechanistic investigation of decolorization and degradation of Reactive Red 120 by Bacillus lentus BI377. Bioresour Technol 102: 758-764.

110. Pagga U, Taeger K (1994) Development of a method for adsorption of dyestuffs on activated sludge. Water Research 28: 1051.

111. Pajot HF, Farina JI, Catellanos FLI (2011) Evidence on manganese peroxidase and tyrosinase expression during decolorization of textile industry dyes by Trichosporon akiyoshidainum. Int Biodeter Biodegr 65: 1199-1207.

112. Papic S, Koprivanac N, Bozic AL (2004) Metes A Removal of some reactive dyes from synthetic wastewater by combined Al (III) coagulation/carbon adsorption process. Dyes and Pigments 62: 291.

113. Parshetti GK, Telke AA, Kalyani DC, Govindwar SP (2010) Decolorization and detoxification of sulfonated azo dye Methyl Orange by Kocuria rosea MTCC 1532. J Hazard Mater 176: 503-509.

114. Pasti-Grigsby MB, Paszczynski A, Goszczynski S, Crawford DL, Crawford RL (1992) Influence of aromatic substitution patterns on azo dye degradability by Streptomyces spp. and Phanerochaete chrysosporium. Appl Environ Microbiol 58: $3605-3613$ 
Citation: Shah MP (2016) Industrial Wastewater Treatment: A Challenging Task in the Industrial Waste Management. Adv Recycling Waste Manag 2: 115 . DOI: $10.4172 / 2475-7675.1000115$

Page 11 of 11

115. Perumal SM, Munuswamy D, Sellamuthu PS, Kandasamy M, Thangavelu KP (2007) Biosorption of textile dyes and effluents by Pleurotus florida and Trametes hirsuta with evaluation of their laccase activity. Iran J Biotechnol 5 114-118.

116. Phugare SS, Kalyani DC, Patil AV, Jadhav JP (2011) Textile dye degradation by bacterial consortium and subsequent toxicological analysis of dye and dye metabolites using cytotoxicity, genotoxicity and oxidative stress studies. J Hazard Mater 186: 713-723.

117. Phugare SS, Kalyani DC, Surwase SN, Jadhav JP (2011) Ecofriendly degradation, decolorization and detoxification of textile effluent by a developed bacterial consortium. Ecotox Environ Saf 74: 1288-1296.

118. Ponraj $M$, Jamunarani $P$, Zambare $V$ (2011) Isolation and optimization of culture conditions for decolorization of True Blue using dye decolorizing fungi. Asian J Exp Biol Sci 2: 270-277.

119. Porri A, Baroncelli R, Guglielminetti L, Sarrocco S, Guazzelli L, et al (2011) Fusarium oxysporum degradation and detoxification of a new textileglycoconjugate azo dye (GAD). Fungal Biol 115: 30-37.

120. Pricelius S, Held C, Sollner S, Deller S, Murkovic M, et al. (2007) Enzymatic reduction and oxidation of fibre-bound azo-dyes. Enzyme Microbiol Technol 40: $1732-1738$

121. Priya B, Uma L, Ahamed AK, Subramanian G, Prabaharan D (2011) Ability to use the diazo dye C. I. Acid Black 1 as a nitrogen source by the marine cyanobacterium Oscillatoria curviceps BDU92191. Bioresour Technol 102: 7218-7223.

122. Rajee O, Patterson J (2011) Decolorization of azo dye (Orange MR) by an autochthonous bacterium Micrococcus sp. DBS 2. Indian J Microbiol 51: 159-163.

123. Ramalho PA, Scholze H, Cardoso MH, Ramalho MT, Oliveira-Campos AM (2002) Improved conditions for the aerobic reductive decolourisation of azo dyes by Candida zeylanoides. Enzyme Microb Technol 31: 848-854.

124.Rau J, Knackmuss HJ, Stolz A (2002) Effects of different quinoid redox mediators on the anaerobic reduction of azo dyes by bacteria. Environ Sci Technol 36: 1497-1504.

125. Rau J, Maris B, Kinget R, Samyn C, Van den Mooter G, et al. (2002) Enhanced anaerobic degradation of polymeric azo compounds by Escherichia coli in the presence of low-molecular-weight redox mediators. J Pharm Pharmacol 54: 1471-1479.

126. Rau J, Stolz A (2003) Oxygen-insensitive nitroreductases NfsA and NfsB of Escherichia coli function under anaerobic conditions as lawsone-dependent azo reductases. Appl Environ Microbiol 69: 3448-3455.

127. Rizzo L (2011) Bioassays as a tool for evaluating advanced oxidation processes in water and wastewater treatment. Water Res 45: 4311-4340.

128. Robinson T, McMullan G, Marchant R, Nigam P (2001) Remediation of dyes in textile effluent: a critical review on current treatment technologies with a proposed alternative. Bioresour Technol 77: 247-255.

129. Ruiz-Arias A, Juarez-Ramirez C, de los Cobos-Vasconcelos D, Ruiz-Ordaz N, Salmeron-Alcocer A, et al. (2010) Aerobic biodegradation of a sulfonated phenylazonaphthol dye by a bacterial community immobilized in a multistage packed-bed BAC reactor. Appl Biochem Biotechnol 162: 1689-1707.

130. Russ R, Rau J, Stolz A (2000) The function of cytoplasmic flavin reductases in the reduction of azo dyes by bacteria. Appl Environ Microbiol 66: 1429-1434.

131. Savin II, Butnaru R (2008) Wastewater characteristics in textile finishing mills. Environ Eng Manage J 7: 859-864.

132. Semde R, Pierre D, Geuskens G, Devleeschouwer M, Moes AJ (1998) Study of some important factors involved in azo derivative reduction by Clostridium perfringens. Int J Pharm 161: 45-54.

133. Shah V, Verma P, Stopka P, Gabriel J, Baldrian P, et al. (2003) Decolorization of dyes with copper (II)/organic acid/hydrogen peroxide systems. Applied Catalysis B: Environmental 46: 287.

134. Slokar YM, Marechal AM-L (1998) Methods of decoloration of textile wastewaters. Dyes and Pigments 37: 335.

135. Soares GMB, de Amorim MTP, Costa Ferreira M (2001) Use of laccase together with redox mediators to decolourize Remazol Brilliant Blue R. J Biotechnol 89: 123-129.

136. Solis-Oba M, Eloy-Juarez M, Teutli M, Nava JL, Gonzalez I (2009) comparison of advanced techniques for the treatment of an indigo model solution: electro incineration, chemical coagulation and enzymatic. Rev Mex Ing Quim 8: 275-282.
137. Stolz A (2001) Basic and applied aspects in the microbial degradation of azo dyes. Appl Microbiol Biotechnol 56: 69-80.

138. Svobodova K, Senholdt M, Novotny' C, Rehorek A (2007) Mechanism of Reactive Orange 16 degradation with the white rot fungus, Irpex lacteus Process Biochem 42: 1279-1284.

139. Swaminathan K, Sandhya S, Sophia AS, Pachhade K, Subrahmanyam YV (2003) Decolorization and degradation of $\mathrm{H}$-acid and other dyes using ferroushydrogen peroxide system. Chemosphere 50: 619.

140. Tauber MM, Gubitz GM, Rehorek A (2008) Degradation of azo dyes by oxidative processes: Laccase and ultrasound treatment. Bioresour Technol 99: 4213-4220

141. Tony BD, Goyal D, Khanna S (2009) Decolorization of textile azo dyes by aerobic bacterial consortium. Int Biodeter Biodegr 63: 462-469.

142. Torrades F, García-Montañ, J, García-Hortal JA, Domènech X, Peral J (2004) Decolorization and mineralization of commercial reactive dyes under solar light assisted photo-Fenton conditions. Solar Energy 77: 573.

143. Tzitzi M, Vayenas DV, Lyberatos G (1994) Pretreatment of textile industry wastewaters with ozone. Wat Sci Tech 29: 151.

144. Van der Zee FP, Bisschops IAE, Blanchard VG, Bouwman RHM, Lettinga G Field JA, (2003) The contribution of biotic and abiotic processes during azo dye reduction in anaerobic sludge. Water Res. 37: 3098-3109.

145. Wafaa M, El-Rahim A, Moawad H (2010) Testing the performance of small scale bioremediation unit designed for bioremoval/enzymatic biodegradation of textile azo dyes residues. New York Sci J 3: 77-92.

146. Waghmode TR, Kurade MB, Govindwar SP (2011) Time dependent degradation of mixture of structurally different azo and non azo dyes by using Galactomyces geotrichum MTCC 1360. Int Biodeter Biodegr 65: 479-486.

147. Waghmode TR, Kurade MB, Kabra AN (2012) Govindwar SP. Degradation of Remazol Red Dye by Galactomyces geotrichum MTCC 1360 leading to increased iron uptake in Sorghum vulgare and Phaseolus mungo from Soil. Biotechnol Bioeng 17: 117-116.

148. Walker R, Ryan AJ, (1971) Some molecular parameters influencing rate of reductions of azo compounds by intestinal microflora. Xenobiotica 1: 483-486.

149. Weisburger JH (2002) Comments on the history and importance of aromatic and heterocyclic amines in public health. Mutat Res 506: 9-20.

150. Wu J, Kim KS, Sung NC, Kim CH, Lee YC (2009) Isolation and characterization of Shewanella oneidensis WL-7 capable of decolorizing azo dye Reactive Black 5. J Gen Appl Microbiol 55: 51-55.

151. Yang Q, Li C, Li H, Li Y, Yu N (2009) Degradation of synthetic reactive azo dyes and treatment of textile wastewater by a fungi consortium reactor. Biochem Eng J 43: 225-230.

152. Yang Q, Yediler A, Yang M, Kettrup A (2005) Decolorization of an azo dye Reactive Black 5 and $\mathrm{MnP}$ production by yeast isolate: Debaryomyces polymorphus. Biochem Eng J 24: 249-253.

153. Yemendzhiev H, Alexieva Z, Krastanov A (2009) Decolorization of synthetic dye Reactive Blue 4 by mycelial culture of white-rot fungi Trametes versicolor 1. Biotechnol Biotec Eq 23: 1337-1339.

154. Yoo ES (2002) Chemical decolorization of the azo dye Cl Reactive Orange 96 by various organic/inorganic compounds. J Chem Technol Biotechnol 77: 481-485.

155. Yusuff RO, Sonibare JA (2004) Characterization of textile industries' effluents in Kaduna Nigeria and pollution implications. Global Nest: Int J 6: 212-221.

156.Zhang W, An T, Xiao X, Fu J, Sheng G, et al. (2003) Photoelectrocatalytic degradation of reactive brilliant orange $K-R$ in a new continuous flow photoelectrocatalytic reactor. Catalysis A: General 255: 221.

157. Zhuo R, Ma L, Fan F, Gong Y, Wan X, et al. (2011) Decolorization of different dyes by a newly isolated white-rot fungi strain Ganoderma sp. En3 and cloning and functional analysis of its laccase gene. J Hazard Mater 192: 855-873.

158.Zimmermann T, Gasser F, Kulla H, Leisinger T (1984) Comparison of two bacterial azoreductases acquired during adaptation to growth on azo dyes. Arch Microbiol 138: 37-43.

159.Zimmermann T, Kulla H, Leisinger T (1982) Purification and properties of orange II-azoreductase from Pseudomonas KF46. Experientia 38: 1380. 